\title{
First report of cassava torrado-like virus, cassava polero-like virus and cassava new alphaflexivirus associated with cassava frogskin disease in Brazil
}

\author{
Saulo Alves Santos de Oliveira ${ }^{1}$ (D) Claudia Fortes Ferreira ${ }^{1} \cdot$ Maria Selma Alves Silva Diamantino $^{1}$. \\ Taís Araújo Santos ${ }^{2} \cdot$ Jocilene dos Santos Pereira $^{2} \cdot$ Eder Jorge de Oliveira ${ }^{1}$
}

Received: 25 June 2019 / Accepted: 29 July 2019 / Published online: 5 August 2019

(C) Società Italiana di Patologia Vegetale (S.I.Pa.V.) 2019

Keywords Manihot esculenta Crantz $\cdot$ Disease etiology $\cdot$ Cassava frogskin disease complex $\cdot$ Identification

Cassava (Manihot esculenta Crantz) plants with typical symptoms of frogskin disease (CFSD) have been observed since 2012 in Cruz das Almas, Bahia, Brazil. The above ground parts of the plants were asymptomatic, however, the roots showed typical symptoms of woody-like appearance, thickened cork-like peel, opaque aspect, and coalescent lip-like slits in a honeycomb pattern. Plants did not test positive for phytoplasma based on a nested-PCR reaction for the $16 \mathrm{~S}$ region (Alvarez et al. 2009). Therefore, we hypothesized a viral infection. To verify our hypothesis, total RNA was extracted from $0.5 \mathrm{~g}$ of plant tissue using CTAB followed by reverse transcription and polymerase chain reaction with specific primers for: (i) cassava frogskin-associated virus - $\mathrm{CsFSaV}$; (ii) 'cassava torrado-like virus' - CsTLV; (iii) 'cassava polerolike virus' - CsPLV and (iv) 'cassava new alphaflexivirus' CsNAV, as described by Carvajal-Yepes et al. (2014). Amplicons were obtained for CsTLV (RNA1: $834 \mathrm{bp}$, RNA2: 719 bp), CsNAV (1227 bp) and CsPLV (1001 bp). No amplicons were obtained for $\mathrm{CsFSaV}$. PCR products were sequenced in both directions, manually edited and deposited in the NCBI database: CsTLV (MN194209, MN194210 and MN194211) and RNA 2 (MN194212, MN194213 and MN194214), CsPLV (MN172358, MN207078 and MN207079) CsNAV (MN207080, MN207081 and MN207082). A BLASTn analysis of the viral sequences showed 96-100\% identity with CsTLV (RNA1 polyprotein: KC505250), CsTLV (RNA2 polyprotein: KC505251); CsPLV (RNA-dependent RNA polymerase and coat protein: KF885738) and CsNAV (replicase, TGB1, TGB2, and coat protein: KC505252 and KY288516), respectively (E-value $<0.001)$. The three putative virus species $($ CsTLV, CsNAV and CSPLV) were described for the first time by CarvajalYepes et al. (2014) on association with CFSD together with $\mathrm{CsFSaV}$ in Colombia. To our knowledge this is the first report of these three viruses associated with CFSD in Brazil.

\section{References}

Alvarez E, Mejía JF, Llano GA, Loke JB, Calari A, Duduk B, Bertaccini A (2009) Characterization of a phytoplasma associated with frogskin disease in cassava. Plant Dis. 93:1139-1145. https://doi. org/10.1094/PDIS-93-11-1139

Carvajal-Yepes M, Olaya C, Lozano I, Cuervo M, Castaño M, Cuellar WJ (2014) Unraveling complex viral infections in cassava (Manihot esculenta Crantz) from Colombia. Virus Res 186:76-86. https:// doi.org/10.1016/j.virusres.2013.12.011

Publisher's note Springer Nature remains neutral with regard to jurisdictional claims in published maps and institutional affiliations.

Saulo Alves Santos de Oliveira

saulo.oliveira@embrapa.br

1 Embrapa Mandioca e Fruticultura (CNPMF), Cruz das Almas, Bahia 4438-0000, Brazil

2 Universidade Federal do Recôncavo da Bahia (UFRB), Cruz das Almas, Bahia 4438-0000, Brazil 